\title{
Wastewater treatment in petroleum activities: example of "SEWAGE" unit in the BG Tunisia Hannibal plant
}

\author{
Lotfi Ghnainia $^{1} \cdot$ Mabrouk Eloussaief $^{2} \cdot$ Kamel Zouari $^{1} \cdot$ Chedly Abbes $^{1}$
}

Received: 3 July 2015/ Accepted: 24 November 2015/Published online: 19 January 2016

(C) The Author(s) 2016. This article is published with open access at Springerlink.com

\begin{abstract}
This paper provides a detailed analysis of the sewage system procedure, as well as the occurring problems during the operation of the system and the required corrective actions that should be taken. In the Hannibal gas plant, the used water is exploited from a local deep well drilled in the plant. However, before being used in both of gas process and domestic activities, this water is treated in a specified unit called "Metito Unit" to obtain an overpurified water that can meet with the chemical requirements of the oil/gas process and the health and environment standards. After several steps of the process, the polluted wastewater resulting from several activities within the plant is treated in the "Sewage Unit". This unit decontaminates wastewater from polluting factors, using the "Extended Aeration Method". We have shown that in spite of the efficient methods used in the sewage system procedure, several problems can occur during the operating of the system such as hydraulic overloading, high SVI, high Fm ratio, which causes high level of organic pollutants $\quad($ BOD5 $=42 \mathrm{mg} / \mathrm{l}), \quad$ chemical pollution $(\mathrm{COD}=85 \mathrm{mg} / \mathrm{l})$, high level of $\mathrm{pH} 8$, chloride $(1900 \mathrm{mg} /$ $1)$, and iron $(8300 \mathrm{mg} / \mathrm{l})$. We suggest that the quality of the treated wastewater should be improved by the addition of other processes such as constructed wetland process, photo-catalytic oxidation technique which is one of the
\end{abstract}

Lotfi Ghnainia

lotfi.ghnainia@yahoo.fr

1 Laboratoire de Radio-Analyse et Environnement, Ecole Nationale d'Ingénieurs de Sfax, Route de Soukra Km 4, Sfax, Tunisie

2 Laboratoire « Eau, Energie et Environnement »(LR3E), Code: AD-10-02, Ecole Nationale d'Ingénieurs de Sfax, Université de Sfax, B.P.W3038, Sfax, Tunisie most efficient methods of wastewater treatment, to produce water quality that is very similar to that of the natural waters.

Résumé Généralement, de très importantes quantités d'eau sont utilisées dans le secteur d'activités pétrolières pour les procédés du raffinage du pétrole et/ou du gaz ainsi que pour les usages domestiques dans la raffinerie. Les eaux usées qui résultent après les dernières étapes du traitement du pétrole ou du gaz seront rejetées dans la nature après avoir subir un traitement d'épuration pour être compatible avec les normes standard de préservation de l'environnement. Dans ce contexte, nous nous proposons d'étudier l'exemple de l'unité de traitement des eaux usées (sewage unit) dans la raffinerie Hannibal de traitement du gaz naturel de la compagnie BG Tunisia. Dans le chantier Hannibal, situé à $23 \mathrm{~km}$ au sud de Sfax, les eaux utilisées sont explorées d'un puits local creusé dans le chantier lui même, ces eaux sont d'abord traitées dans une station d'épuration appelée Metito unit, et ce avant d'être utilisées dans les différentes unités du chantier et les différentes activités domestiques. Après cet usage, les eaux résiduelles sont polluées et sont pour ce fait traitées dans une unité spécifique appelée Sewage Unit dans laquelle les eaux usées passent par des opérations physiques, chimiques et biologiques permettant leur décontamination autant que possible des facteurs polluants. La technologie appliquée dans l'unité de traitement des eaux usées "sewage unit" est basée sur la méthode dite "méthode d'aération poussée". Cette méthode consiste en quatre opérations principales à savoir: le criblage ou dépistage, l'aération, la stabilisation et la chloration. Dans le présent travail, nous venons de montrer que malgré la haute performance de l'unité de traitement des eaux et l'efficacité des équipements utilisés, des problèmes peuvent survenir dans le procédé 
d'épuration et seront à l'origine de la modification de la qualité des eaux usées qui seront loin des normes standards de préservation d'environnement, d'où la nécessité d'envisager d'autres solutions beaucoup plus efficaces pour la résolutions de tels problèmes.

Keywords Wastewater - Management - Sewage system . Extended aeration method - Settling - Chlorination · Screening

Mots clefs Eaux usées - Traitement - Sewage unit . Méthode d'aération poussée $\cdot$ Criblage $\cdot$ Chloration . Stabilisation

\section{Introduction}

The increasing rates of human water consumption and the rapidly growing world population have resulted in water preservation jumping to the forefront of global issues [15]. Because of the necessity of water for human survival as well as living organism, there is a need to appropriately manage the use of this valuable resource. An important aspect of responsible water management is the development of new methods of wastewater treatment [6, 7]. Large volumes of wastewater are generated daily by various industrial processes, and the implementation of efficient treatment technologies would lead to immense ecological and economic benefits [8]. The efficient purification of petrochemical wastewater has become one of the most important issues in the last years. There is evidence that the biological purification of petrochemical wastewater can be carried out with activated sludge supplied with nutrients and oxygen [9, 10]. It has also been recognized that several processes such us activated sludge and constructed wetlands methods are suitable for the treatment of wastewater incoming from oil refineries $[11,12]$.

For the biological aerobic treatment and the operation of activated sludge systems, the $\mathrm{C}: \mathrm{N}: \mathrm{P}$ ratio is important. A ratio of 100:15-10:1 is often recommended [13, 14].

Several new technologies in petrochemical wastewater treatment are now appearing like treatment by means of clean electrochemical technologies [15-17], enhanced biodegradation using ozonation [18], anaerobic digestion [19] and aerobic systems [20].

The constructed wetlands technique is one of the posttreatment technologies of petrochemical wastewater, but their operation is greatly influenced by environmental factors. The post-treatment of the purified wastewater is then carried out assured in a constructed wetland, which consists of a pre-settling pond unit, an oxidation pond unit and a post-settling reed pond [21]. In the post-treatment pond system, about $50 \%$ efficiency of elimination of organic materials expressed as COD or TOC is acceptable [22, 23].

Among the various wastewater treatment technologies, degradation of organic pollutants by Photo-Catalytic Oxidation $(\mathrm{PCO})$ has received much attention in recent years and is emergent as an effective treatment technique [24]. The PCO has several advantages over traditional methods, via, complete mineralization of pollutants, no requirement for disposal of sludge, and low energy consumption. In the PCO process, the most widely used catalyst is $\mathrm{TiO}_{2}(\mathrm{Ti}-$ tanium dioxide) because of its ability for oxidizing a wide range of organic pollutants and also because of its low cost [25].

Generally, for the textile wastewater, the biological aerobic wastewater systems are not successful for decolourization of majority of dyes. Photo-catalysis has been successfully used to oxidize this dye by many workers [26].

Moreover, the applicability of adsorption in the removal of heavy metals has been investigated by multiple researchers [27-31]. These studies confirmed the potential use of adsorption as an appropriate technique for the removal of various heavy metals.

Great quantities of water are used in the petrochemical activities, for both oil and gas process and also domestic activities such as restaurant and administration building. In the Hannibal gas treating plant within BG Tunisia, the used water is exploited locally by a deep well drilled in the plant.

Before being used in the plant, the water is treated in a specific unit called METITO Unit that provides an overpurified water eventually used in different steps of the gas process and for domestic activities.

Like the majority of Oil and Gas plants, the Hannibal gas treating plant is situated in a location where no local sewage facilities are available. Therefore, to safeguard as possible the environment, a package sewage system, called SEWAGE Unit, has been installed. The package has been designed to accept and treat all domestic sewage products from the complex. The plant is capable of treating up to 75 $\mathrm{m}^{3} /$ day of raw sewage.

In this paper, our study will be focused on the sewage system procedure. The operation of the sewage system using the extended aeration method is discussed. The optimization of the sewage system, the occurring problems during operation, and the adequate corrective actions are also discussed, with suggestions of suitable processes (PCO, adsorption, constructed wetlands) for post-treatment of the petrochemical wastewater already treated by the activated sludge method. 


\section{Localization}

The investigations were carried out in the Hannibal gas treating plant, the samples have been analyzed during the first 10 days of july 2011 into the HSSE department (Health, Security, Safety and Environment department) in the Hannibal plant within BG Tunisia.

BG Tunisia gas company is a part of the international oil/Gas company called BG group (the world leader in natural Gas). This company, supplying more than $60 \%$ of domestic gas in Tunisia, was established since 1994. The gas, exploited from the Miskar field located in the Golf of Gabes, is treated in the Hannibal plant situated in the village of Nakta-Bouakkazine, $23 \mathrm{~km}$ to the south of Sfax, southern Tunisia (Fig. 1).

The mixture of gas, condensate, saline water and other materials such as $\mathrm{H}_{2} \mathrm{~S}, \mathrm{CO}_{2}$, and waste water, incoming from the Miskar Platform, is treated during the several steps of process in several units of the Hannibal plant (Fig. 1). The water exploited from the local well is necessary for this process especially for the Glycol Unit.

\section{Equipments, methods and process description of sewage system}

\section{Equipments}

In the sewage unit, we can discern the following equipments (Fig. 2):
- Sewage Treatment Plant Blowers, C-2601 A/B,

- Blower Control Logic,

- Sewage Lift Station Pump,

- Sewage Surge Tank Pumps,

- Sewage Lift Station,

- Sewage Surge Tank,

- Sewage Treatment Plant.

\section{Methods}

The water used in the Hannibal plant is exploited from a local well drilled in the plant. This water is treated in the METITO unit using several techniques: chlorination, primary and secondary filtration, primary and secondary reverse osmoses, and ion's exchanger resins. The result of this treatment is an over-purified water stored in a big tank of water process.

The pure stream sewage treatment system in the Hannibal plant is based on the extended aeration method of sewage treatment. This method consists basically of four operations: screening, aeration, settling and chlorination. Sometimes, additional operations may be required to overcome abnormal local conditions, including the disposal of any "Off spec" effluent by trucking to local authority disposal plant.

\section{Screening}

When the sewage first enters the plant, it passes through a screening device. This consists of a series of bars welded

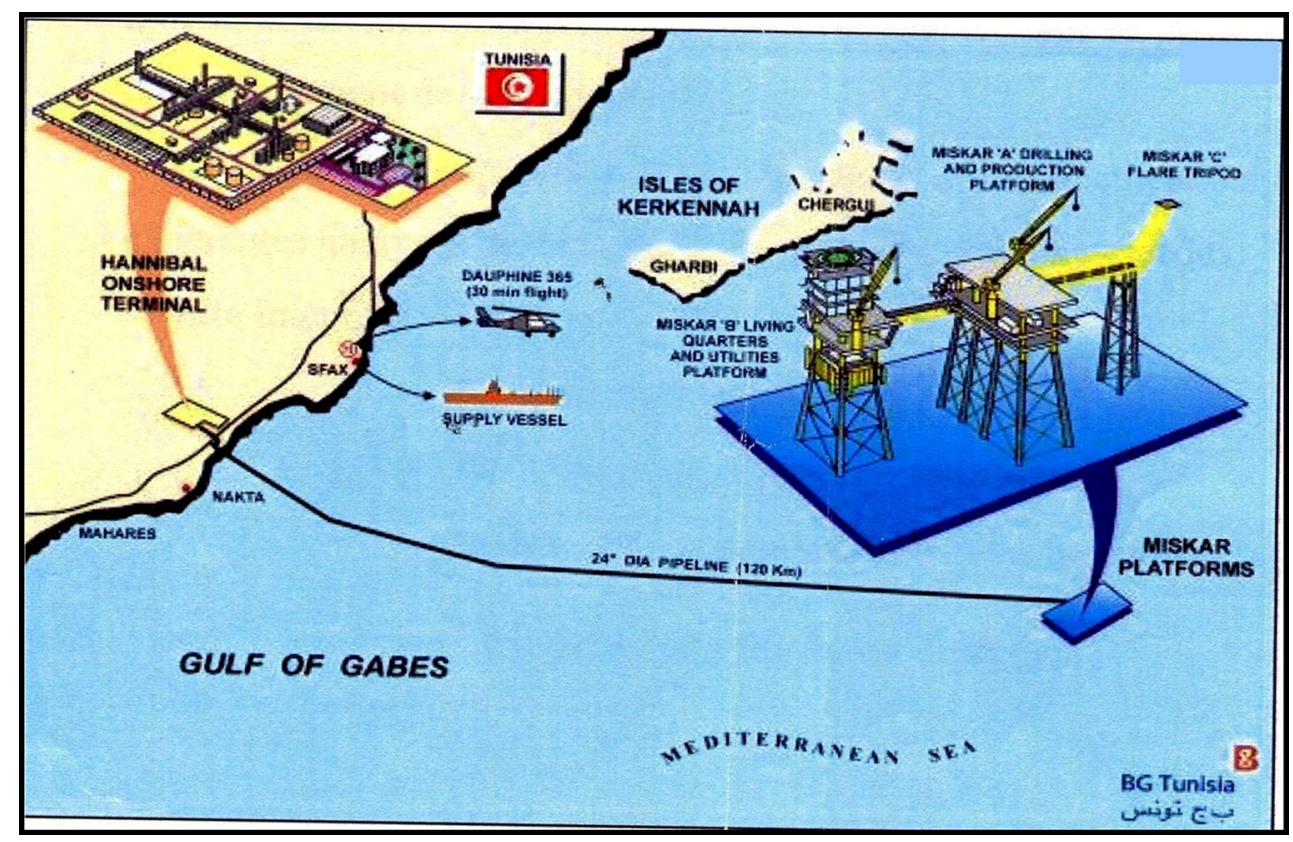

Fig.1 Miskar platforms and Hannibal Plant Localizations 


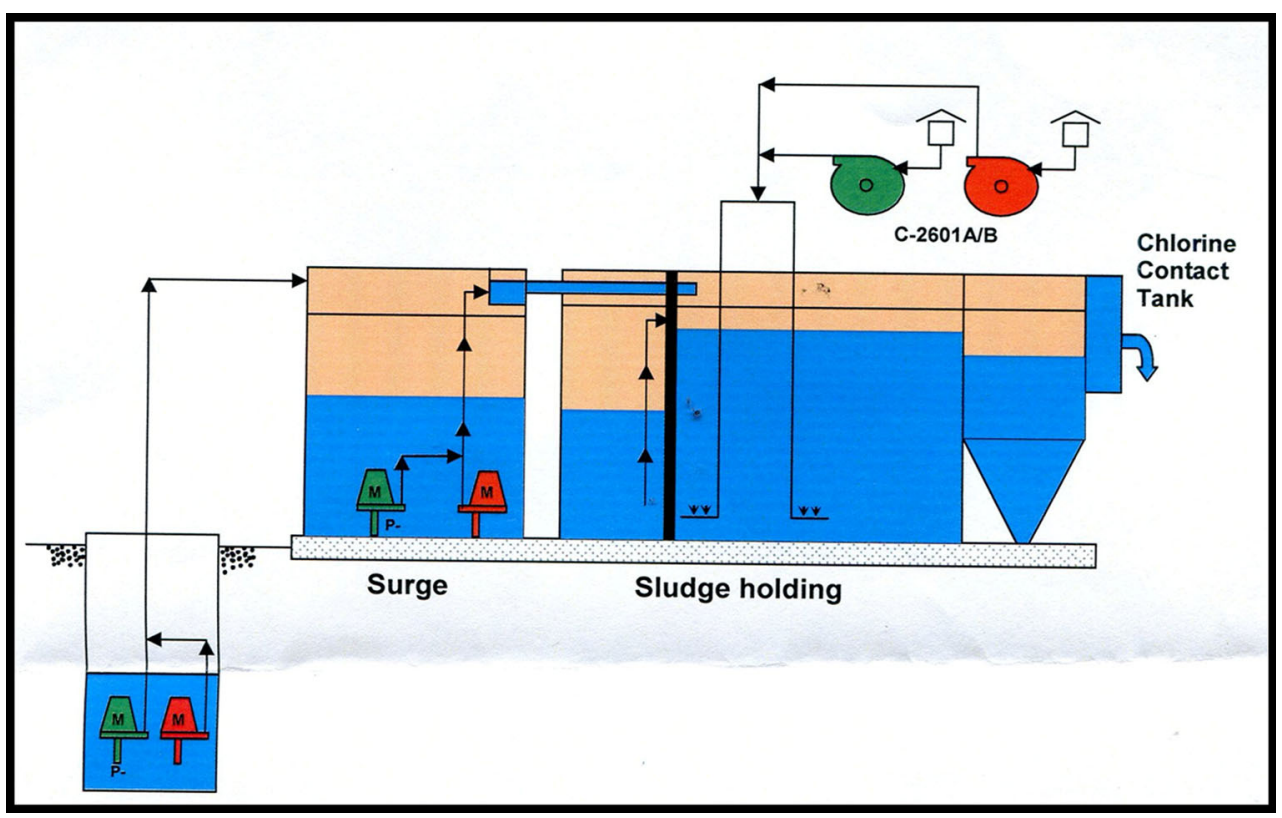

Fig.2 Sewage system and equipments

into a "via" shaped frame with approximately one inch spacing between the bars. The purpose of this device is to trap any larger particles which may have passed through the pumps, from entering the system.

\section{Aeration}

From the screening device, the sewage passes into the aeration tank. Here, the sewage is decomposed by aerobic bacteria and other organisms in the presence of air (aerobic conditions). In a properly operating plant, these micro-organisms (bugs) will form a dark brown mass called "activated sludge". The incoming sewage mixes with this activated sludge by the introduction of air, blown through diffusers at the bottom of the tank. This mixing of the liquids through the supply of air currents allows the organisms to decompose the sewage into carbon dioxide, water and some other minor constituents: phosphates, nitrates and sulfates.

\section{Settling}

From the aeration tank, the treated sewage/activated sludge mixture passes through a port in the wall into the settling tank or clarifier. Here, the heavier activated sludge mass settles to the bottom and the clear treated liquid flows over a weir and into the discharge line. The retention time within this section is usually $4 \mathrm{~h}$. The settled sludge or bacteria is then returned back to the aeration tank by the air lift sludge return system.

\section{Chlorination}

The effluent discharged by the clarifier then passes through a chlorination package that kills any disease-carrying bacteria, which might be found in the effluent. The liquids pass through a tablet-fed chlorinator with a 30-min retention time, before plant discharge.

\section{Process description of the sewage system}

The sewage unit is operating as the following manner: (1) raw sewage and domestic waste water collected from the administration building, restaurant, warehouse, and control room, combined in the underground system. This waste flows into the Sewage Lift Station and when the high level is reached, the lift station pump P-2601 A or B (Fig. 2) is activated to pump the sewage water into the sewage surge tank; (2) the raw sewage enters the surge tank after passing through a barred screen that separates any large solids from the flow; (3) the surge tank operates under level control and when the liquid reaches float switch FS-2 the lead pump starts; (4) the sewage is pumped from the bottom of surge chamber into the flow control box; (5) air for the surge tank is supplied by the Plant Air System (PAS) and regulated to 0.34 barg by a pump called PVC-26002; (6) the sewage coming from the surge tank is pumped into a flow control device by a pump named P-2602A/B (Fig. 2); (7) the aeration tank is the mainstay operation of the whole treatment unit. Here, the sewage is decomposed by aerobic bacteria and other organisms in the presence of air into 


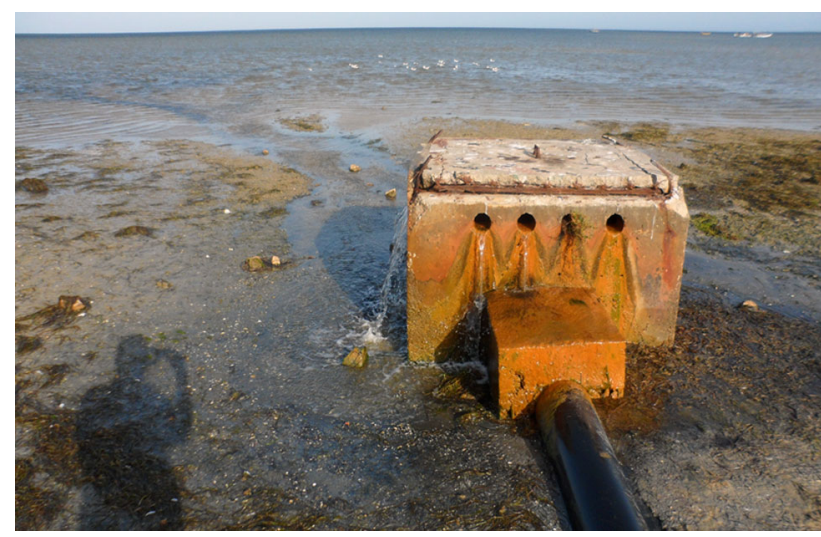

Fig.3 Treated water coming from Sewage Unit and rejected in the sea

carbon dioxide and water and other minor constituents; (8) from the aeration tank, the treated sewage mixed with the activated sludge passes into the settling tank or clarifier where the heavy activated sludge mass settles to the bottom and the clear treated liquid flows over a weir into the discharge line; (9) the settled sludge or bacteria is returned back to the aeration tank to decompose more incoming sewage; (10) the treated liquid (the effluent) discharged from the settling tank then passes through a chlorination unit; this is done to kill the disease-carrying (pathogenic) bacteria, which might be in the effluent. The treated effluent passes through the contact tank where a tablet feed chlorinator mixes with the solution prior to being discharged by a special pipe line in the Sea (chaffar-nakta beach), (Fig. 3).

\section{Results and discussions}

\section{The sewage daily checks}

During routine daily checks, utilizing the daily check sheet (Table 1), we-area technician-will notify the shift superintendent of any anomalies according to the sewage procedure. Anomalies in the sewage system can be detected by checking the following parameters (Table 2), especially in the treated liquid (effluent) prior to being discharged.

During normal working hours, the shift superintendent will notify the laboratory supervisor to investigate, in case to ensure that the sewage is in specifications (Table 2) if not the area technician will divert the outfall from the field to the recycle line back to the unit.

In addition to the daily checks, the parameters are coherently followed at regular periods, and a meeting of the concerned department is organized in the end of each period to discuss the evolution of the system and the
Table 1 Sewage plant data

\begin{tabular}{ll}
\hline Daily flow rate & $15-25 \mathrm{~m}^{3}$ \\
Aeration volume & $109 \mathrm{~m}^{3}$ \\
Surge tank volume & $22.7 \mathrm{~m}^{3}$ \\
Clarifier volume & $12.6 \mathrm{~m}^{3}$ \\
Sludge holding tank volume & $16.7 \mathrm{~m}^{3}$ \\
\hline
\end{tabular}

Table 2 Sewage parameters and normal specifications

\begin{tabular}{ll}
\hline Parameters & $\begin{array}{l}\text { N.T.106.03 } \\
\text { discharge limits }\end{array}$ \\
\hline $\mathrm{pH}$ & $6.50-8.50$ \\
Conductivity(Micro s/cm) & 7000.0 \\
$\mathrm{COD}(\mathrm{mg} / \mathrm{l})$ & 90.0 \\
$\mathrm{BOD}_{5}(\mathrm{mg} / \mathrm{l})$ & 30 \\
$\mathrm{TSS}(\mathrm{mg} / \mathrm{l})$ & 30 \\
Chloride $(\mathrm{mg} / \mathrm{l})$ & 2000 \\
Iron $(\mathrm{mg} / \mathrm{l})$ & 5000 \\
\hline
\end{tabular}

Table 3 Sewage parameter's followed during 10-day period

\begin{tabular}{lllllll}
\hline Sample & pH & Conductivity & COD & BOD $_{5}$ & Chloride & Iron \\
\hline Sp 1 & 7.5 & 6800 & 85 & 20 & 1800 & 6000 \\
Sp 2 & 6 & 7600 & 75 & 20 & 1900 & 6500 \\
Sp 3 & 6 & 7500 & 78 & 25 & 1900 & 6000 \\
Sp 4 & 6.5 & 7500 & 70 & 20 & 1900 & 5000 \\
Sp 5 & 7 & 6900 & 70 & 20 & 1800 & 5500 \\
Sp 6 & 7.5 & 7000 & 70 & 20 & 1600 & 6000 \\
Sp 7 & 7.5 & 7100 & 85 & 42 & 1600 & 7500 \\
Sp 8 & 8 & 6800 & 85 & 40 & 1500 & 8000 \\
Sp 9 & 8 & 6000 & 80 & 40 & 1800 & 8300 \\
Sp 10 & 7 & 6300 & 65 & 38 & 1900 & 6800 \\
\hline
\end{tabular}

problems that occurred during the last period. The aim required from this regular following is to study the parameter's evolution and identify the most frequent problems occurred during the sewage system operating. An example of this consistent following in the first 10 days of July month 2009 is illustrated in the Table 3 . We can note the High level of $\mathrm{BOD}_{5}$ in the last 4 days from 07/07 to $10 / 07$; such anomalies show that a problem of aeration occurs in the treatment system.

\section{Occurring problems in the sewage system and preferred alternatives}

During normal operation, the system is totally automatic and is properly adjusted, thus the plant will have the following appearance: 
Table 4 Poor performance symptoms and appropriate corrective actions

\begin{tabular}{ll}
\hline Symptoms of poor performance & Corrective actions \\
\hline $\begin{array}{l}\text { Hydraulic overloading } \\
\text { Low SSV }\end{array}$ & Reduce RAS \\
Increased sludge blanket depth & Increase RAS \\
Low MLSS & \\
Low MLSS, low GSA, high SVI, & Reduce WAS \\
$\quad$ high FM ratio & \\
High MLSS, low SVI, high GSA, & Increase WAS \\
low FM ratio & \\
Rising solid, high DO & Reduce aeration time \\
Low DO & Increase aeration time \\
\hline
\end{tabular}

- Aeration tank: air bubbles rising, medium brown color

- Settling tank: surface clear and liquid clear to depth of 18 or more inches

- Effluent: clear, sparkling. No solids, more than $1 \mathrm{ppm}$ D.O.

While the sewage system is in operation, poor performance symptoms could appear and corrective actions must be done immediately. Some of the problems that could occur are listed below:

- Diffuser or airline blockage;

- Over aeration;

- Sludge not returning;

- Skimming not returning;

- Excessive foaming.

We can list examples of such problems and appropriate corrective actions that should be taken, in the following Table 4.

The outlet from the sewage treatment plant normally flows to the leaching field irrigation for dispersion; however, there are other routes which may be used if problems occur; if the laboratory analysis of the effluent shows the discharge to be out of specifications, and then the flow to the leaching field must be stopped.

The preferred alternative dispersal route now becomes the contactors vacuum truck to the local municipality sewage plant which we call "ONAS".

Other dispersal routes available for the outlet effluent include returning it back to the lift station for recycling or routing it to the open ditch where it mixes with excess outflow from the well water. The two valves in the pit adjacent to the tank are used to divert the effluent either to the leaching field irrigation or back to the open ditch which takes the excess well water alongside the administration building-this is not an approved route.

At no time, unfortunately, the effluent shall be discharged to the sea (Fig. 3) from the sewage treatment plant and the sewage disposal becomes a serious problem when it is knowingly out of the acceptable specification limits stipulated by Tunisian Law.

The extended aeration method should be carried on with combination of other processes. The constructed wetland technique is one of the post-treatment technologies of petrochemical wastewater, but their operation is greatly influenced by environmental factors. The post-treatment of the purified wastewater is then carried out assured in a constructed wetland, which consists of a pre-settling pond unit, an oxidation pond unit and a post-settling reed pond. In the post-treatment pond system, about $50 \%$ efficiency of elimination of organic materials expressed as COD or TOC is acceptable.

We suggest the treatment using the Photo-Catalytic Oxidation method. In fact, various researchers have reported the photo-catalytic degradation of large variety of organic pollutants using $\mathrm{TiO} 2$. The heavy metal removal can be carried on by the adsorption technique using prepared adsorbents.

\section{Conclusion}

The sewage treatment system in the Hannibal gas plant is based on the extended aeration method (Biological Aerobic Treatment and Activated Sludge System). The main important equipment in this system is the Sewage Treatment Plant that consists of four separate compartments contained in one rectangular structure (sludge holding tank, aeration tank, clarifier and chlorination contact tank). This system is running since 1994, and despite this continuous operation over several years, the ecological structure and the functioning of the system is still acceptable. However, we have to note that the daily measurements of several parameters (especially $\mathrm{pH}, \mathrm{COD}, \mathrm{BOD}_{5}, \mathrm{TOC} \ldots$ ) of the discharged treated liquid (effluent) show serious problems related to the environment protection, in fact the effluent incoming from the discharge line is not perfectly compatible with the required specifications (high level of BOD5 and COD) and so that it will be dangerous on the life of micro and macro-organisms in this part of the sea.

During any period when the outlet water from the clarifier fails to meet the required specifications, the liquids can be routed back into the Sludge Holding tank and this is situated at the very front end of the unit. The problem in this case is that the capacity of this tank less than $16 \mathrm{~m}^{3}$, and the excess sludge removed from the clarifier should not be stored if the aeration tank is full of sludge, thus a problem of aeration could occur in the aeration tank. The liquids or sludge transferred here (into the Sludge Holding tank) have to be removed by truck and it is not the approval solution. It is one among many problems that could occur during the operating of the system. 
Moreover, an emergency shutdown has no effect on the sewage system and this is a serious problem that should be resolved as soon as possible. The wastewater quality could be improved by the installation of posttreatment processes using effective technologies. The implementation of constructed wetlands is suitable; however, the operation of such process is greatly influenced by environmental factors. We suggest the treatment using Photo-Catalytic Oxidation (PCO) technique; the efficiency of this technology in the removal of organic pollutants has been approved.

Acknowledgments Thanks are extended to Mr Faicel Hajbi, Laboratory supervisor within BG Tunisia Hannibal Gas Plant for facilitating the analysis of samples in the Sewage Treatment Plant using several methods and techniques. This work was done during a training session in the HHSE department within BG Tunisia. We insist that there is no conflict of interest in this work. The authors would like to thank both the reviewers for helpful comments and suggestions.

Open Access This article is distributed under the terms of the Creative Commons Attribution 4.0 International License (http:// creativecommons.org/licenses/by/4.0/), which permits unrestricted use, distribution, and reproduction in any medium, provided you give appropriate credit to the original author(s) and the source, provide a link to the Creative Commons license, and indicate if changes were made.

\section{Appendix}

- Activated sludge: organisms produced by the aerobic decomposition of waste water.

- Chemical oxygen demand (COD): the amount of chemically oxygen disable materials present in the waste water.

- Biochemical oxygen demand (BOD5): the amount of organic matter which can be biologically oxidized under controlled conditions (5 days, $20^{\circ}$ in the dark).

- Waste activated sludge (WAS): the quantity of suspended solids in the sludge which are removed from the activated sludge process.

- Return activated sludge (RAS): the quantity of suspended solids in the sludge which are returned to the aeration tank.

- Mixed liquor suspended solids (MLSS): the suspended solid concentration in the mixed liquor.

- Settled sludge volume (SSV): Amount of sludge available.

- Sludge volume index (SVI): volume occupated by one gram of sludge.

- Gould sludge age (GSA): age of sludge in the aeration tank based on inlet TSS and MLSS values.

\section{References}

1. Allen R (2012) Water sustainability and the implementation of the water framework directive-a European perspective. Ecohydrol Hydrobiol 12:171-178

2. Alok M, Dipika K, Arti M, Jyioti M, Gupta VK (2009) Adsorption studies on removal of colouring agent phenol red from wastewater using waste materials as adsorbents. J Colloids Interface Sci 337:345-354

3. Alok M, Jyotti M, Arti M, Dipika K, Gupta VK (2009) Adsorptive removal of hazardous anionic dye "congo red" from wastewater using materials and recovery by desorption. J Colloids Interface Sci 340:16-26

4. Alok M, Jyotti M, Arti M, Dipika K, Gupta VK (2010) Decoloration treatment of a hazardous triarylmethane dye, light green sf (yellowish) by waste material adsorbent. J Colloids Interface Sci 342:518-527

5. Alok M, Jyotti M, Arti M, Dipika K, Gupta VK (2010) Removal and recovery of chrysoidine $\mathrm{Y}$ from aqueous solution by waste materials. J Colloids Interface Sci 344:497-507

6. Eloussaief M, Hamza W, Kallel N, Benzina M (2013) Wastewaters decontamination: mechanisms of $\mathrm{Pb}(\mathrm{II}), \mathrm{Zn}$ (II) and $\mathrm{Cd}(\mathrm{II})$ competitive adsorption on Tunisian smectite in single and multisolute system. Environ Prog Sustain Energy J 32(2):229-328

7. Eloussaief M, Bouaziz S, Kallel N, Benzina M (2013) Valorisation of El Haria clay in the removal of arsenic from aqueous solution. Desalination Water Treat. doi:10.1080/19443994.2013. 795877

8. Gupta VK, Rajeev J, Alok M, Tawfik AS, Arunima N, Shilpi A, Shalini S (2012) Photo-catalytic degradation of toxic dye amaranth on $\mathrm{TiO} 2 / \mathrm{UV}$ in aqueous suspensions. Mater Sci Eng C 32:12-17

9. Atlas RM (1984) Petroleum microbiology. Macmillan Publishing company, New York

10. Lakatos G (1986) Biological wastewater treatment of oily wastewater. Környezettudományi kutatások II, 43-77 (in Hungarian)

11. Hawkes HA (1983) Stabilization Ponds. In: Curds CR, Hawkes HA (eds) Ecological aspects of used water treatment, vol 2. Academic Press, London, pp 163-217

12. Lakatos G (1998) Constructed wetlands for wastewater treatment in Hungary. In: Vymazal J, Brix H, Cooper PF, Green MB, Haberl $\mathrm{R}$ (eds) Constructed wetlands for wastewater treatment in Europe. Backhuys Publishers, Leiden, The Netherlands, pp 191-206

13. Bitton G (1994) Wastewater Microbiology. John Wiley and sons, Inc. Publication, New York

14. Henze M, Herremoes P, Junson J, Aarvin E (1995) Wastewater treatment, biological and Chemical processes. Springer-Verlag, Berlin

15. Dimoglo HY, Akbulut FC, Karpuszu M (2004) Petrochemical wastewater treatment by means of clean electrochemical technologies, clean technologies and environmental policy 6

16. Jain AK, Gupta VK, Bhatnagar A, Sushas (2007) A comparative study of adsorbents prepared from industrial wastes for removal of dyes. Sep Sci Technol 38:463-481

17. Ottaviano JG, Cai J, Murphy RS (2014) Assessing the decontamination efficiency of a three component flocculating system in the treatment of oilfield produced water. doi:10.1016/j.watres. 2014.01.004

18. Chi-Kang L, Tsang Yeuh T, Juinn-Ching L, Mei-Chih Ch (2001) Water Res 35:699

19. Macarie H (2005) Overview of the application of the anaerobic treatment to chemical and petrochemical wastewaters. Water Sci Technol 42:201-213 
20. Tawfik AS, Gupta VK (2012) Photo-catalyzed degradation of hazardous dye methyl orange by use of a composite catalyst consisting of multi-walled carbon nanotubes and titanium dioxide. J Colloids Interface Sci 371:101-106

21. Lakatos G, Zoltan V, Janos K, Ilona M (2014) The management and development of constructed wetlands for treatment of petrochemical waste waters in Hungary: 35 years of experience. Ecohydrol Hydrobiol. doi:10.1016/j.ecohyd.2014.01.007

22. Mohan D, Gupta VK, Srivastava SK, Chander S (2001) Kinetics of mercury adsorption from wastewater using activated carbon derived from fertilizer waste. Colloids Surf A Physicochem Eng Asp. doi:10.1016/S0927-7757(00)00669-5

23. Engelder T, Cathles LM, Bryindzia LT(2014). The fate of residual treatment water in gas shale. J Unconv Oil Gas Resour 7:33-48

24. Gupta VK, Rajeev J, Alok M, Arunima N, Shilpi A, Meenakshi S (2011) Removal of hazardous dye-Tartrazine by photo-degradation on titanium dioxide surface. Mater Sci Eng C 31:1062-1067

25. Gupta VK, Nayak A (2012) Cadmium removal and recovery from aqueous solutions by novel adsorbents prepared from orange peel and $\mathrm{Fe}_{2} \mathrm{O}_{3}$ nanoparticles. Chem Eng J 180:81-90
26. Gupta VK, Shilpi A, Tawfik AS (2011) Synthesis and characterisation of alumina-coated carbon nanotubes and their application for lead removal. Hazard Mater J 185:17-23

27. Gupta VK, Srivastava SK, Mohan D, Sharma S (1997) Design parameters for fixed bed reactors of activated carbon developed from fertilizer waste for the removal of some heavy metal ions. Waste Manag 17:517-522

28. Gupta VK, Jain R, Varshney S (2007) Process development for the removal of zinc and cadmium from wastewater using slag-a blast furnace waste material. Sep Sci Technol 32:2883-2912

29. Gupta VK, Carrott PJM, Ribeiro Carrott MML, Suhas (2009) Low-cost adsorbents: growing approach to wastewater treatmenta review. Crit Rev Environ Sci Technol 39:783-842

30. Gupta VK, Rastogi A, Nayak A (2010) Adsorption studies on the removal of hexavalent chromium from aqueous solution using a low cost fertilizer industry waste material. J Colloid Interface Sci 342:135-141

31. Hadi K, Mohammed KR, Pezhman A, Gupta VK, Zahra V (2010) Multi-walled carbon nanotubes-ionic liquid-carbon paste electrode as a super selectivity sensor: application to potentiometric monitoring of mercury ion. Hazard Mater J 183:402-409 